\title{
Fragmentos da condição feminina e a lógica jurídica no início da república: Recife (1920-1940)
}

\section{Inocência da Silva Galvão Neta}

Resumo: Esse artigo tem como objetivo discutir sobre a violência nas relações de gênero no início do século XX. Especificamente nas décadas de vinte e trinta. Nele, nós pretendemos investigar como se apresentava a condição feminina dentro da lógica jurídica. Utilizamos os documentos da justiça para analisar os registros dos abusos cometidos contra as mulheres pobres. Os procedimentos criminais dessa época nos remetem aos relatos das vítimas, advogados, juízes e réus e através deles observamos que era um tempo de confrontos entre tradição e modernidade e de uma legislação que consolidava as desigualdades de gênero. Tempo em que havia uma estrutura legal que também refletia o pensamento patriarcal brasileiro: O código criminal de 1890 . Os testemunhos das mulheres das camadas populares foram vistos como reivindicações sobre vários tipos de violência cometidos contra elas nos relacionamentos amorosos.

Palavras-chave: violência, legislação, gênero, classes populares, início do século XX.

Abstract: This paper aims at discussing about the violence in gender relationships in the beginning of the $20^{\text {th }}$ century, specifically in the decades of twenty and thirty. In this article we intend to discuss about the juridical and logical female condition. We use law documents to analyze the legal records of abuses against poor women. The criminal proceedings of that time bore the reports of witnesses, lawyers, judges, victims and defendants. A time in which tradition and modernity confronted one another, and of a legislation that consolidated gender inequalities. A legal structure that also reflected the thought of Brazilian patriarchal structure: the Criminal Code of 1890. These testimonies were seen as a share of women's claims of various types of violence committed against them, the low female class, in romantic relationships.

Keywords: violence, legislation, gender, low classes, beginning of the $20^{\text {th }}$ century.

Artigo recebido em 08/12/2015 e aprovado em 10/03/2015. 


\section{INOCÊNCIA DA SILVA GALVÃO NETA}

A violência nas relações de gênero é o objeto central desse estudo. Nossa análise dos abusos cometidos contra o sexo feminino foi produzida a partir da leitura de uma série de fontes da justiça no início do século XX em Recife. Os documentos em foco representam um ínfimo objeto da história dos delitos cometidos nas relações de gênero em Recife, nos primeiros decênios do século XX. Eles revelam uma pequena parte desse aspecto, pois nós historiadores podemos observar apenas o que foi registrado ou ainda melhor o que ficou nos arquivos da justiça e foi catalogado para que pudéssemos refletir sobre as agressões cometidas contra as mulheres e a condição feminina. A reflexão de Verônica Ferreira sobre o que é a violência nas relações de gênero diz que a mesma:

(...) representa um fenômeno social complexo cuja particularidade merece ser estudada e analisada à luz de um contexto mais geral de relação patriarcal, de legitimação da violência contra a mulher e de desigualdades baseadas na classe e na raça/cor, historicamente construídas de modo particular em nosso Estado [Pernambuco] (...) $)^{\mathrm{II}}$

Desse modo, ao analisarmos a documentação judiciária levamos em consideração todas essas características. A de que nosso exame deve partir da relação patriarcal que, de certo modo, legitima a violência contra o sexo feminino, juntamente com outros tipos de desigualdade advindas, não apenas das diferenças de classe, mas também da cor.

Por conseguinte, a documentação da justiça no início do século XX apresenta inúmeras informações reveladoras para a historiografia sobre a condição das mulheres e o funcionamento das relações conjugais nos casos de violência, sobretudo, as pertencentes às camadas populares. Nos processos-crime ou em partes deles, como os inquéritos, apelações e em toda sorte de fontes encontradas nos arquivos da justiça, há uma infinidade de depoimentos de testemunhas, contendo, entre outros aspectos, informações que mostram como se davam as querelas nas relações de gênero. Neles, consta igualmente, o tratamento dispensado a uma parcela da população feminina, isto é, as que compunham as camadas populares.

A partir das fontes analisadas nesse estudo, há inúmeros elementos sobre como eram examinados e julgados os abusos que as mulheres sofriam. Além disso, estes dados servem de subsídio para sabermos como eram as relações entre a justiça e a população e as apreciações dos jurisconsultos e das testemunhas sobre questões que levam a conhecer um pouco da caracterização social e da contextualização de ocorrências como: tentativas e efetivações de homicídios, variados tipos de lesões corporais, como os estupros, espancamentos, etc.

O código penal ao qual estão subordinados os processos da época em estudo é o de 1890, o qual já é uma reformulação das leis de 1830 que, por sua vez, foi o primeiro do Brasil pós-independência. ${ }^{\text {III }}$ Tais mudanças foram necessárias por causa do fim da escravidão que tornou a normatização do início do século XIX obsoleta, pois, a partir da abolição todos os artigos que se referiam aos cativos tornaram-se sem sentido. As disposições legais de 1890 vigoraram até 1940. Estendendo-se, portanto, por todo o período estudado até 1941 quando a legislação em questão sofre transformações.

Com a República foi "inaugurada" toda uma política higienizadora e disciplinadora dos $\operatorname{corpos}^{\mathrm{IV}}$, a questão dos bons costumes e da moral, seriam, então extremamente importantes para que fossem alcançados os objetivos dos governos. ${ }^{\mathrm{V}} \mathrm{A}$ historiadora social Martha Abreu Esteves, afirma que, esse processo de mudanças se inicia justamente no final do Império e se estende até os primeiros decênios do século XX. Essas transformações, além de estarem ligadas à transição do trabalho escravo para 


\section{INOCÊNCIA DA SILVA GALVÃO NETA}

o livre e assalariado, significaram também, do ponto de vista político e social, a formação da ordem burguesa no Brasil.

Quando analisamos os documentos, compreendemos o peso que há sobre essa questão, ao percebermos que se leva em conta para o veredicto dos autos e até para o julgamento das ações cotidianas nos jornais, é apenas a lei. Melhor explicando, a interpretação da lei com base nos costumes. Nos autos, vemos que a mulher considerada juridicamente incapaz é ponto pacífico para que os juízes deem ganho de causa ou abrandem a punição aos maridos, companheiros ou qualquer indivíduo do sexo masculino que houvesse cometido alguma agressão ou delito contra o sexo oposto. É obvio que há igualmente o peso dos costumes. As leis consuetudinárias, inclusive, têm tudo a ver com a elaboração dos documentos que regem uma sociedade. São elas que dão "o norte" para a elaboração dos códigos, ou seja, é a essência das leis, em qualquer época.

Contudo, Bobbio mostra que o conceito de "justo", quando é utilizado para o homem pode significar um indivíduo respeitador das leis ou possuidor de equidade em julgar. Enfim, entendemos que a palavra igualdade não cabe para um julgamento de um homem que agride uma inferior, uma juridicamente incapaz. Um indivíduo cujo dever é ser obediente e bem comportada: a mulher.

As matérias dos jornais quando se referem à mulher que apanhou "sem motivo justificado" estão intimamente ligadas à noção de "justo". Elas remetem ao significado de sujeitos que possuem uma particular autoridade. ${ }^{V I}$ Portanto, quando um juiz avaliava um delito praticado por um marido, companheiro, noivo, namorado ou amásio, o sentenciava baseado numa equanimidade que, ...respeitou a regra geral do igual tratamento dos iguais, VII não cabendo, portanto, no tema em questão, já que as mulheres não eram consideradas e tampouco tratadas como iguais. Nem nos meios jurídicos, na legislação ou mesmo nos costumes.

Já foi exaustivamente explorada, na literatura sobre gênero, a condição subalterna feminina, cuja sujeição historicamente construída, representa um ponto fundamental neste trabalho, visto que é baseada nisso que se solidifica outra construção histórica: a inferioridade das mulheres perante os homens.

A frequência dos casos de violência contra o sexo feminino, encontradas nos registros da justiça, superaram nossas expectativas. Os arquivos mostram que os diversos tipos de delito não eram tão raros como pensamos. Encontramos neles, além dos perfis dos agentes envolvidos, traços do cotidiano das mulheres pobres da cidade do Recife. Dos documentos catalogados, não encontramos dificuldades, em absoluto, em localizar várias histórias de mulheres espancadas, estupradas, assassinadas e também nos deparamos com muitos defloramentos. Este último é muito mais frequente na documentação criminal.

Tal delito, considerado crime de estupro quando cometido contra mulheres menores ${ }^{\text {VIII }}$, pode não ser concebido como violência num primeiro momento. De fato, em alguns casos não o é. Há casos nos quais os casais o fazem de comum acordo. Noutros, a moça o pratica com a esperança de casar-se. Em se tratando de relações amorosas e coisas afins, pode haver uma infinidade de motivos para que tais eventos ocorram. No entanto, as consequências de tal ato podem ser avaliadas também como truculência, pois sabemos bem o que poderia acontecer a essas mulheres quando se sabia que já não eram mais "honradas", "honestas".

Há dois casos de espancamento que nos contam muito sobre a visão de grande parte da sociedade sobre as mulheres que não eram consideradas dignas de respeito. $\mathrm{O}$ primeiro é sobre uma senhora que foi presa e espancada por dois guardas civis, ${ }^{\text {IX }}$ na 


\section{INOCÊNCIA DA SILVA GALVÃO NETA}

prisão ${ }^{\mathrm{X}}$. Tratava-se do inquérito instaurado na Comarca do Recife contra dois guardas civis, os quais foram enquadrados no artigo 231 e $303^{\mathrm{XI}}$ das leis penais da época, por terem espancado à borracha, Maria A. S., no xadrez da própria delegacia, quando estavam em pleno expediente. Os acontecimentos que antecedem a prisão valem à pena ser detalhados.

Assim, a referida mulher encontrava-se tomando café, pouco antes da meia noite, num estabelecimento chamado Café Radiante, o qual se localizava na Rua Diario de Pernambuco; quando dois guardas a prenderam, segundo a vítima, sem dizer palavra, isto é, sem anunciar o motivo da prisão.

De início, podemos considerar que era sim uma atitude considerada "suspeita" pela polícia, uma mulher sozinha num Café, àquela hora da noite, era - na época atitude "suspeita", simplesmente por ser um comportamento não aceito pela sociedade, já presumindo tratar-se de prostituição ${ }^{\mathrm{XII}}$. E tampouco era costume das mocinhas casadoiras e de boa reputação andarem pelas ruas desacompanhadas. Sobretudo tarde da noite. ${ }^{\text {XIII }}$ Podemos até pensar se não teria, de fato, sido o caso da moça estar praticando o trottoir $^{X I V}$. Possivelmente. No entanto, a atitude dela, o fato de estar altas horas sozinha na rua, aparentemente, não é a causa da prisão. Segundo a vítima, além das autoridades em questão, não terem dito o motivo, a mantiveram durante toda a noite no xadrez. No dia seguinte, eles alegaram que queriam fazer a limpeza da cela e a levaram para fora.

Depois disso, espancaram-na com uma borracha, pois segundo seu depoimento, os dois a surraram, ao mesmo tempo. Um deles estava com uma borracha nas mãos enquanto o outro lhe dava ponta pés e socos. Consta no processo o exame feito em Maria. Nele contém a descrição detalhada do laudo médico, com todas as marcas das agressões, provando que ela havia apanhado com o instrumento citado. Assim, constava nos autos,

(...) que o guarda Renato.G.O. espancou-a barbaramente a borracha a declarante enquanto o guarda Eduardo.G.M. andava dando ponta pés e borbotões; que. a seguir o guarda Eduardo.G.M. levou a declarante para o banheiro, dando-lhe um banho $(. . .)^{\mathrm{XV}}$

Todo esse quadro descrito acima ultrapassa todos os limites da falta de humanidade e de respeito, pois se tratava de uma pessoa totalmente vulnerável, a qual estava à mercê de duas autoridades que usaram de violência e humilhação para intimidá-la. Além disso, tais atitudes dos guardas os guardas no exercício de suas funções, já é considerado abuso de autoridade e crime. No entanto, encontramos um motivo que pode explicar, em parte, as agressões. Segundo a vítima, o fato dela ter servido de testemunha contra os dois num inquérito policial militar, teria sido o motor que os levou a praticarem tais atos. No documento consta que a vítima apanhou duas vezes na delegacia e que, o segundo espancamento, ocorreu durante a prisão, por ela ter comentado com a companheira de cela sobre o ocorrido. Inclusive, Maria teria contado para a mulher, que havia sido testemunha no inquérito no qual os dois estavam envolvidos.

A questão é que Maria A. S. foi examinada pelo IML e o laudo apontou que todos os ferimentos relatados por ela de fato haviam ocorrido. Em todo o documento, sobretudo na parte do Instituto de Medicina Legal, há o perfil da pessoa examinada. Tais características revelam a classe social à qual pertence a vítima. Nesse caso, sabemos que tinha 21 anos, era parda, solteira, analfabeta e doméstica. Mais uma vez nos deparamos com características, as quais, na maioria das vezes, eram de mulheres 


\section{INOCÊNCIA DA SILVA GALVÃO NETA}

que pertenciam às camadas populares e portanto, em princípio eram tidas como pessoas sem moral, e como já mencionamos, possíveis prostitutas.

Principalmente por estar tão tarde, "perto das 24 horas", na rua. Já aludimos que mesmo com todas as propagandas da modernidade sobre a valorização do espaço público, a tradição imperava. Contradições da modernidade. Os costumes ditavam qual o comportamento que uma boa moça deveria ter e estar nas ruas desacompanhada e além do mais a altas horas, definitivamente, não era um deles. Muito mais vigiadas seriam, então, as mulheres do povo, pois também já analisamos que a população pobre era muito mal tratada, por diversas razões, como também, não eram bem vindos às ruas. Sua presença nas vias centrais era sinônimo de desordem. ${ }^{\text {XVI }}$

Voltando às características de Maria, ela já possuía todo um perfil que a colocava em descrédito. Todos os atributos desta mulher a punham em desvantagem com relação às autoridades que, por sua vez, possuíam o dever de cuidar da cidade, no sentido de manter a boa ordem e o bem estar dos cidadãos. Ela não tinha o perfil da mulher "higienizada", portanto, era considerada uma "chaga social". Era tida com alguém que deveria ser extirpado da sociedade devido aos seus "vícios" e esse conceito talvez tenha contribuído para o resultado do processo. Mesmo com toda a descrição dos maus tratos que o IML descreveu no exame ${ }^{\text {XVII }}$ o resultado não foi favorável para a moça.

Ressaltamos que no rol das testemunhas havia duas mulheres, as quais depuseram sobre o caso e forneceram pistas sobre a prisão e os maus tratos sofridos pela vítima. Uma, inclusive, foi testemunha ocular da prisão de Maria.

Uma dessas mulheres é Antonia, de 18 anos, solteira, filha de pais ignorados, analfabeta e moradora do Pátio do Carmo, $\mathrm{n}^{\circ} 6,1^{\circ}$ andar. Constava também que ambas moravam na mesma casa, e ela relatou que,

a sua companheira estava tomando leite em o Café Radiante, quando cerca de meia noite fôra presa pelo guarda civil Renato. G. O., que estava destacado nesta delegacia que, Renato prendera sua companheira por que fôra testemunha em um inquerito militar, feito na região, em cujo inquerito o alludido guarda dita mulher vinha sendo perseguida pelo guarda alludido, pelo facto da mesma mulher ter servido como testemunha num inquerito policial militar, em que esteve envolvido o alludido guarda e seu companheiro Eduardo. G. M. também guarda civil (...) ${ }^{\mathrm{XVIII}}$ (Grifo nosso).

Sobre como Maria A. S. havia saído da prisão, com a ajuda de duas autoridades, Antonia informa,

que a dona da casa onde reside a mulher Maria. A., procurou o sargento E., que havia funccionado no inquerito policial militar que, o alludido sargento, com o tenente, procedente e o inquerito, trataram de intervir, sendo a mulher posta em liberdade (...) $)^{\mathrm{XIX}}$ (Grifo nosso).

O depoimento acima dá a entender que Maria saiu da prisão, com certa brevidade, graças ao auxílio dos dois militares que estavam envolvidos no inquérito instaurado contra os guardas civis. O fato de esses dois indivíduos terem ido soltá-la, nos faz imaginar o que teria ocorrido com a mulher que fora presa e espancada, caso não tivesse sido solta graças à intervenção de duas autoridades. Talvez ela tivesse permanecido na prisão por mais algum tempo e nem tivesse sobrevivido aos maus tratos. Possivelmente.

A outra mulher, também testemunha ocular da prisão de Maria A. S., chamavase Maria do Carmo e era dona da casa onde as três moravam, no endereço citado. Tinha 20 anos, era solteira e analfabeta. Contou que estava passando pelo Café Radiante, pouco antes das 24 horas, quando viu o guarda civil Renato. G. O. prender a sua companheira e, afirmou que, 


\title{
INOCÊNCIA DA SILVA GALVÃO NETA
}

\begin{abstract}
a declarante veio a saber $\log$ que Maria A. foi solta, que tinha sido espancada no xadrez desta delegacia que, a declarante chegou a ver as ecchymoses apresentadas por Maria A.; que não sabe o motivo da prisão. ${ }^{\mathrm{XX}}$
\end{abstract}

Esta também era uma testemunha importante, pois, como a outra, afirmava ter visto a prisão de Maria. Contudo, quando as testemunhas são novamente chamadas a depor para o juiz, todas, sem exceção, dizem não saber de coisa alguma. Ademais, o depoimento de um dos guardas civis é extremamente desfavorável à vitima. Ele contou que Maria havia sido presa porque, além de estar na rua numa hora imprópria, também estava embriagada. $\mathrm{O}$ outro certamente contribuiu muito para que não fosse levado em conta nem a prova concreta, o laudo do IML. O que nos reporta ao fato da medicina ser, de fato, também no caso do Recife, auxiliar importante do direito, pois a ciência médica não estava no mesmo patamar da jurídica, para alguns teóricos da época, como ficou claro no $3^{\circ}$ capítulo desse trabalho. Mas, voltemos ao depoimento de um dos guardas civis, Eduardo G. M. Nas palavras dele Maria A. S.

(...) depois que curtiu a carraspana foi posta em liberdade que dita mulher que depois que soube chamar-se Maria, depois de ter curtido a carraspana que teve liberdade, disse ter sido espancada, que, entretanto, tal facto não é verdade, pois se Ella apresenta contusões pelo corpo, naturalmente foram produzidas quando a mesma no estado de embriaguez, efusiva batia de encontro a grade do xadrez. (Grifos nossos).

A declaração do guarda Eduardo G. M. já coloca Maria A. S. como uma mulher que não merece nem um tipo de crédito, pois era uma mulher "da rua" e "sem moral". No entender da maioria, nessa época, uma pessoa do sexo feminino com essas características não inspirava confiança, sobretudo estando bêbada. Observamos que o último argumento foi repetido diversas vezes durante o processo. Sendo assim, o fato de ela ter sido espancada é justificável para os padrões da época, pois veladamente, há o apoio do Estado e da própria sociedade para que uma moça com esse perfil seja punida e isolada do meio social. Além do fato de ser uma possível prostituta.

Como já foi mencionado, o final do processo não é favorável à moça. O juiz concluiu que o número de testemunhas era mínimo e que não havia, portanto, nenhuma prova que fosse demasiado contundente para que os réus fossem condenados. Notamos que os depoimentos do inquérito das duas mulheres, mesmo tendo sido bastante reveladores, não foram suficientes para a condenação dos guardas civis. Sobretudo porque no segundo momento, quando deveriam estar na presença do juiz para as audiências, nenhuma delas sustentou o que disse no princípio. Mesmo Maria A. S. tendo sido examinada pelo IML, cujo laudo aponta diversas marcas e ferimentos, que coincidem com o período em que ficou presa e não tendo contradições acerca do que ela afirmou, ainda assim, para as autoridades, não havia provas suficientes para a condenação dos guardas.

O segundo caso é sobre outro espancamento. XXI Tratava-se de Cleonilda G. S. ${ }^{\text {XXII }}, 17$ anos, doméstica, parda e com 1 metro e cinquenta de altura ${ }^{\text {XIIII }}$. Consta que ela havia se casado com Luiz Henrique, de 23 anos, moreno, profissão de propagandista. Já numa das primeiras páginas encontramos o inquérito instaurado, na delegacia do segundo distrito, contra Luiz Henrique, por ter deflorado ${ }^{\text {XIV }}$ a menor Cleonilda em 1938.

Vemos que já havia um começo complicado para a história do relacionamento dos dois, que Cleonilda havia sido deflorada pelo que viria a ser seu futuro marido. Não significaria nada se fosse apenas o início de uma história de amor, porém, para a justiça o delito, por se tratar de uma menor, era considerado crime. Contudo, o "problema" 


\section{INOCÊNCIA DA SILVA GALVÃO NETA}

havia sido "remediado", pois o delegado logo informa, no início do documento que, $o$ acusado havia reparado o primeiro crime casando-se com a vítima. ${ }^{X X V}$.

Adiantamos que tal "solução" para o erro cometido era muito fácil de ser encontrada nos documentos da época, pois a lei, inclusive, a considerava um tipo de recurso para que o mal fosse reparado e o réu absolvido. Martha de Abreu Esteves ao tratar essa questão adverte que o sistema criminal brasileiro possuía duas estratégias para resolver tais desvios da sexualidade feminina, ou seja, para os delitos cometidos contra as "moças honestas": A primeira seria através da punição e a segunda seria através do casamento. Sendo este uma abordagem civilizadora. ${ }^{X X I}$ Atualmente, seria muito mais grave e, por isso, não passível de ser inocentado, principalmente por tratarse de uma menor seviciada.

Não há, hoje em dia, a menor possibilidade de ser considerado um ato consensual ou de haver uma reparação para ele. Pelo menos na teoria, o casamento não seria a solução para tal delito. De qualquer modo, seria considerado estupro por se tratar de menor. Contudo, no início do século XX, o remédio para a sevícia seria simplesmente casar o criminoso com a "moça ofendida". XXVII A questão é que depois de ter "reparado" o primeiro crime, Luiz Henrique não tardou em cometer outro. Em seguida foi acusado de espancar sua jovem esposa, por sinal é esse justamente o motivo do processo. Acontece que Cleonilda, depois do casamento, foi morar com o marido na casa da sogra, onde as surras começaram a acontecer.

Além do mais, no depoimento de uma das testemunhas consta que ele era um sujeito de má reputação. Tratava-se de Josepha S., Pernambucana, solteira, 35 anos, doméstica, sabendo ler e escrever, e mãe da vítima. Ela declara que havia castigado Cleonilda por não aceitar a relação amorosa de sua filha com Luiz Henrique e afirmou que não conhecia o rapaz com o qual sua filha havia iniciado o namoro e, por isso, não concordava com a relação. Informou que chegou a punir a filha por ela estar namorando um desconhecido. Acrescido ao fato dele ser, nas palavras dela, também, um sujeito de "péssimo comportamento". Ela acrescentou que o acusado, Luiz Henrique, chegou a pedir sua filha em casamento e que, mesmo a contragosto, havia aceitado. Embora, em outros depoimentos conste que a menina não havia sequer sido espancada, há relatos que indicam que houve a agressão, confirmada pelo laudo médico, onde consta a presença dos ferimentos sofridos.

O curioso é que, no início do texto, o documento em questão já oferece um indício sobre como esse acontecimento era observado pelas autoridades. Entre as primeiras frases já está claro o pouco caso com o qual a questão era percebida: ...Por questão de menos importância o acusado... espancou a esposa Cleonilda... com quem se casou depois de haver deflorado... ${ }^{\mathrm{XVVIII}}$ Mesmo que se subentenda que o motivo é irrelevante para o delito ou que poderia haver um motivo justificado, também está implícito que pouco importa se a violência aconteceu por desobediência ou por motivos - à época - mais banais, pois, a própria insubordinação da mulher já era considerada falta grave. É sabido que uma das regras desse tempo era que a mulher casada devia obediência ao seu esposo e era dele dependente em vários aspectos; por ser, inclusive, juridicamente incapaz.

Já foi analisado no capítulo anterior o termo "sem motivo justificado" e, através dele e de outros relatos, já considerados previamente, é possível observar que há uma grande aceitação dos castigos corporais, pelo menos os mais brandos, como método de educação para as esposas. Há certa tolerância, mesmo que na maioria das vezes velada, aos corretivos feitos pelos maridos. 


\section{INOCÊNCIA DA SILVA GALVÃO NETA}

Para os espancamentos que passavam dos "limites" havia a comprovação através dos exames médicos. Os documentos judiciais dos delitos como estupros, espancamentos, contém desenhos do IML para mostrar como e quais foram os supostos ferimentos feitos nas vítimas. Para exemplificar bem essa questão, dentre as perguntas dos exames médicos há uma que se refere à gravidade do ferimento. A lesão ter sido leve ou não era levado em conta tanto para o tempo da pena quanto para o próprio resultado do julgamento. Muitas vezes, o fato de ter sido considerado leve denota que nem deve ser levado em conta, pois os advogados de defesa dos acusados utilizam esse pormenor, algumas vezes.

É preciso que notemos que havia toda uma inquirição médica que servia para dar um suporte científico à investigação, para então, haver um quê de verdade absoluta e incontestável no julgamento. Devemos lembrar que o positivismo com seu arcabouço teórico da verdade indiscutível, se revestido da técnica e do conhecimento erudito, oferecia ainda mais possibilidade de apresentar vestígios, na opinião das autoridades da época, quase incontestáveis. Pelo menos de acordo com o as teorias da citada escola de pensamento que "povoava" as cabeças da intelligentsia brasileira durante boa parte do século XX.

\section{Notas}

I Doutora em história pelo Programa de Pós-graduação em história da Universidade Federal de Pernambuco.

II FERREIRA,Verônica. "Violência contra a mulher em Pernambuco: a difícil tarefa de entender o contexto." In CASTILLO - MARTÍN, Márcia e OLIVEIRA, Suely Márcia. (org.). Marcadas a ferro:violência contra a mulher - uma visão multidisciplinar. Brasília: Secretaria especial de políticas públicas para as mulheres, 2005. Op. Cit. p. 181.

III A legislação criminal do Império tinha como base o código criminal de 1830. O código, segundo Caufield, era uma manifestação ousada da filosofia jurídica liberal que ainda estava em fase de implementação em algumas nações europeias, pelos juristas mais progressistas. O dito código foi aprovado pelo legislativo brasileiro, rapidamente; no lugar do livro 5 das Ordenações Filipinas portuguesas de 1603. A autora informa que: Os princípios fundamentais do código penal de 1830 revelavam a inspiração de seus autores no direito clássico que estava começando a prevalecer na Europa. Igualmente importantes foram a influência da Revolução francesa e o desejo de eliminar o que viam como resquícios do regime colonial absolutista: o poder arbitrário do Estado sobre os indivíduos baseado na alegação de que o rei era o representante da vontade divina; a punição excessiva ou por vingança, decidida em alguns casos à mercê da vontade do rei; a distinção entre classes de sujeitos jurídicos, que era a base do privilégio aristocrático; e a fusão da lei com a moralidade. CAULFIELD, Sueann. Em defesa da honra: moralidade, modernidade e nação no Rio de Janeiro (1918-1940). São Paulo: Editora da Unicamp, 2000. p. 58.

IV A normatização da sociedade através de regras morais para a família dentro dos padrões médicos foi iniciada na Europa em fins do XIX. Foucault afirma que a medicina, a pedagogia e depois a psiquiatria respectivamente trataram de elaborar e por em prática essa disciplinarização, essa higienização das relações na família dando maior atenção às mulheres e às crianças. FOUCAULT, Michel. História da sexualidade. 1 a vontade saber. Rio de Janeiro: Edições Graal,1988.

$\mathrm{v}$ Caulfield conta que os juristas que fizeram as leis brasileiras no começo da Primeira República mostraram estar absorvidos com a honra sexual e a virgindade. Que o juiz e professor Francisco José Viveiros de Castro dizia ser o respeito pela honra da mulher uma conquista da civilização e que uma sociedade que não seguia tal comportamento utilizava a "brutalidade dos instintos" como guia. Por essa razão, foi estruturada a já mencionada política higienizadora. CAULFIELD. Sueann. Op. Cit. p. 54.

${ }^{V I}$ BOBBIO, Norberto. BOBBIO, Norberto. MATEUCI, Nicola e PASQUINO. Gianfranco. Dicionário de política. 2 vol., Brasília: Editora UnB, 1995. p.309.

VII BOBBIO, Norberto. Op. Cit. p.309. 


\title{
FRAGMENTOS DA CONDIÇÃO FEMININA E A LÓGICA JURÍDICA NO INÍCIO Dan REPÚBLICA: RECIFE (1920-1940)
}

\author{
INOCÊNCIA DA SILVA GALVÃO NETA
}

\begin{abstract}
VIII Com relação à questão da menor idade, de acordo com o código de 1830, a mulher seria considerada menor até 17 anos. O código republicano ampliou para 21 e presumiu como estupro o crime sexual que fosse cometido contra mulheres de menor idade, isto é, seria considerado como ato violento qualquer que fosse a prática sexual cometida contra a moça honesta que tivesse menos de 16 anos. Sobre o intuito dessa mudança legal, Martha Esteves comenta que essa ampliação da menor idade permitiu o controle de uma maior quantidade de mulheres. Na opinião da autora, essa modificação do código: estendeu o prazo legal de tutela sobre a mulher e garantiu a punição em um maior número de casos. Ela acredita que tal mudança se deveu a causas políticas. Melhor explicando, à política de controle do Estado sobre o sexo feminino, pois, [c] ertamente, mulheres com 20 anos em 1890, pela lógica do "progresso dos costumes", não deveriam ser menos higiênicas, ou melhor, mais ingênuas, que suas antecessoras de 1839. Realmente a mudança de idade teve outras motivações... ESTEVES, Martha de Abreu. Meninas Perdidas: os Populares e o cotidiano do amor no Rio de Janeiro da Belle Époque. Rio de Janeiro: Paz e terra, 1989. p.
\end{abstract} 94.

${ }^{\mathrm{IX}}$ Os guardas civis desempenhavam o papel da polícia judiciária, por essa razão, a função deles era apurar as responsabilidades nas práticas ilícitas. Investigavam a ocorrência do crime, identificavam os responsáveis e encontravam as testemunhas. In IZUMINO, Wânia Pasinato. Justiça e violência contra a mulher: o papel do sistema judiciário na solução dos conflitos de gênero. São Paulo: Annablume: FAPESP, 2004. p. 54.

${ }^{\mathrm{x}}$ Memorial da Justiça, caixa 1, 1936. Réus: Eduardo G. de M. e Renato G. de O. Vítima: Maria A. de S.

${ }^{\mathrm{XI}} \mathrm{O}$ Artigo 231 pertence Capítulo VI, Secção VI, que diz respeito ao excesso ou abuso de autoridade e usurpação de funç̧ões publicas. Enquanto o de número 303 está inserido no capítulo V, que trata das lesões corporaes do código penal de 1820. Ele enquadra os crimes que digam respeito ao - Excesso ou abuso de autoridade e usurpação de funções públicas. Especificamente ele penaliza quem: Art. 231. Commeter qualquer violencia no exercício das funções do emprego, ou a pretexto de exerce-las:

Penas - de perda do emprego, no gráo maximo; de suspensão de tres annos, no médio, e por um anno no mínimo, além das mais em que incorrer pela violencia. BRASIL, Republica Federativa do: Código Penal 1890. Disponível em: http:// www6.senado.gov.br/legislação/ListaPublicações.action? $=66049$. Acesso em: 14/maio/2011; pp. 34 e 46.

XII Clarissa Nunes Maia ao tratar sobre a prostituição no Recife no fim do século XIX e início do XX, afirma que combatê-la era normatizá-la. Em outras palavras, o Estado procurava manter as "mulheres de vida fácil" longe das "boas famílias", pois segundo a autora, há registros da presença destas pessoas nos becos e travessas mais pobres das freguesias do Recife e São José e até mesmo nas pensões chics do bairro de Santo Antônio. Contudo, não foram encontradas referências às "mulheres de má vida" no bairro da Boa Vista nem nos subúrbios onde moravam as pessoas de mais posses na época, o que talvez, denote que o comércio do corpo era tolerado pelas autoridades policiais, apenas, nos locais mencionados anteriormente. Para o Estado, regido pela política higienista, controlar o baixo meretrício era também conter os homens pobres, pois as autoridades acreditavam que o desregramento que levavam estes que mantinham uma vida regada a mulheres, bebidas e desordens, não era adequado ao mundo do trabalho. Julgavam que este tipo de prática era o avesso da estrutura de um lar. Este último seria proveitoso para as aspirações de um capitalismo incipiente por organizar para os afazeres cotidianos, ao estabelecer horários para práticas tais como: acordar, dormir e fazer sexo. Enfim, a ordem existente na estrutura familiar possuía reagras imprescindíveis para a vida do operário, do trabalhador. MAIA, Clarissa Nunes. Policiados: controle e disciplina das classes populares na cidade do Recife, 1865-1915. 250 p. Tese (doutorado), Universidade Federal de Pernambuco, Tese (doutorado), Universidade Federal de Pernambuco, CFCH, Recife, 2001. p. 179-181.

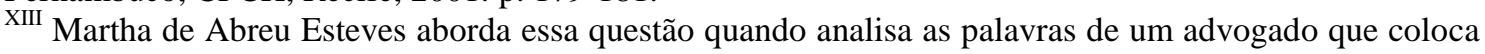
em dúvida a honestidade de uma moça, entre outros motivos, por andar nas ruas "fora de horas". Ela diz que: verdadeiras ou falsas, as palavras do advogado levantam a questão de que andar pelas ruas, fora de hora, e ir a determinados locais considerados impróprios, fazem de Laura uma mulher de vida fácil. ESTEVES, Martha de Abreu. Op. Cit. p. 45.

XIV Expressão utilizada por Laure Adler no livro Os bordéis franceses (1830-1930). São Paulo: Companhia da Letras.1991. Ela significa o ato de estar na rua para procurar clientes.

Fazer trottoir. Exercer a prostituição perambulando pelas ruas para aliciar fregueses. Aurélio Novo Século XXI. O dicionário da língua portuguesa. Versão 3.0. Editora Nova Fronteira. 1999.

${ }^{\mathrm{xV}}$ Memorial da Justiça, caixa 1, 1936. Réus: Eduardo G. de M. e Renato G. de O. Vítima: Maria A. de S.

${ }^{\mathrm{XVI}}$ Beccaria analisa essa questão a qual vale a pena ser comentada, pois é bastante similar a essa lógica do Estado brasileiro, do início do período republicano, a respeito dos pobres. No capítulo que trata dos 
crimes que perturbam a tranquilidade pública afirma que, (...) a arruaça de pessoas que lutam na via pública, que se destina ao comércio e ao trânsito dos cidadãos, e os discursos fanáticos que provocam com facilidade as paixões de um populacho curioso e que emprestam grande força à multidão de ouvintes e especialmente um (sic) certo entusiasmo sem sentido e misterioso, com o poder muito maior sobre o espírito popular do que a calma razão, cuja linguagem a multidão não compreende. Iluminar as cidades no curso das noites à custa do público [que no caso do Recife era muito precária, portanto ao que parece, essa questão não era vista como essencial para a segurança e a tranquilidade pública]; pôr guardas de segurança nos diferentes bairros das cidades; reservar ao silêncio (...) as arengas de moral religiosa, e aquelas destinadas a manter os interesses particulares e públicos (...) essas são as medidas apropriadas para prevenir a perigosa fermentação das paixões populares; e são esses os principais assuntos que devem ocupar a atenção do magistrado de polícia. BECCARIA, Cesare. Dos delitos e das penas. São Paulo: Rideel, 2003. pp. 106 e 107.

${ }_{\mathrm{XVII}}$ Constavam no exame de corpo de delito as seguintes características: echymoses diversas de cor variando do vermelho ao vermelho -violaceo e de dimensões de dois centimetros de extensão por um e meio centimetros de largura e cinco centimetros de extensão por quatro centimetros de largura, nas regiões da nuca, deltroides, supra-escapulares, columna vertebral, escapulares e goteiras costo vertebraes. Constava no exame que, comprovadamente, ela havia sofrido ofensa física. Memorial da Justiça, caixa 1, 1936. Réus: Eduardo G. de M. e Renato G. de O. Vítima: Maria A. de S.

XVIII Memorial da Justiça, caixa 1, 1936. Réus: Eduardo G. de M. e Renato G. de O. Vítima: Maria A. de S. XIX Idem.

${ }^{\text {xx }}$ Memorial da Justiça, caixa 1, 1936. Réus: Eduardo G. de M. e Renato G. de O. Vítima: Maria A. de S.

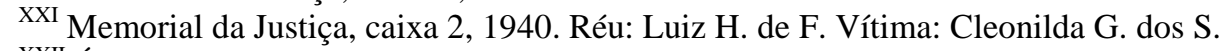

XXII É importante ressaltar que já no início do documento consta um atestado de miserabilidade da vítima. Tal documento é necessário, pois assim a pessoa seria beneficiada com uma ação pública já que devido à sua extrema pobreza não possuía condições para arcar com os custos de um processo. Para maiores detalhes ver o capítulo "Crimes Sexuais" in FAUSTO, Boris. Crime e cotidiano: a criminalidade em São Paulo (1880-1924). 2a ed. São Paulo: Edusp, 2001. pp.193-248.

XXIII Apenas como registro acerca da idade e da altura das mulheres. Quase a totalidade delas possui entre 16 e 21 anos. Devido à questão da punição com relação a pratica de abusos contra menores. No que diz respeito à altura, a maioria possui entre um metro e cinquenta a um e cinquenta e cinco.

XXIV Corresponde, portanto ao Título VIII: Dos crimes contra a segurança da honra e honestidade das famílias e do ultraje publico ao pudor, Capítulo I: da violência carnal. Art. 267 do Código Penal que diz: Deflorar mulher de menor idade, empregando seducção, engano ou fraude. Pena-de prisão cellular por um a quatro annos. P.40. Republica Federativa do Brasil: Código Penal 1890. Loc. Cit. p. 40.

${ }^{\mathrm{Xxv}}$ Memorial da Justiça, caixa 2, 1940. Réu: Luiz H. de F. Vítima: Cleonilda G. dos S.

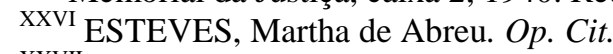

xxvII Expressão utilizada à época pela justiça.

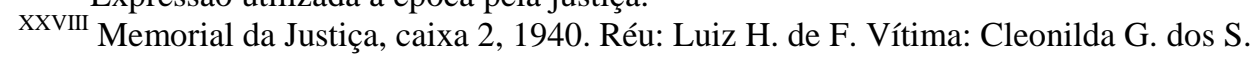

\section{Bibliografia}

ADLER, Laure. no livro Os bordéis franceses (1830-1930). São Paulo: Companhia da Letras.1991.

BECCARIA, Cesare. Dos delitos e das penas. São Paulo: Rideel, 2003.

BOBBIO, Norberto. BOBBIO, Norberto. MATEUCI, Nicola e PASQUINO. Gianfranco. Dicionário de política. 2 vol., Brasília: Editora UnB, 1995.

BRASIL, Republica Federativa do: Código Penal 1890. Disponível em: http://

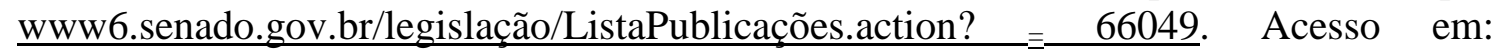
14/maio/2011. 
CASTILLO - MARTÍN e OLIVEIRA, Suely Márcia. (org.) Marcadas a ferro:violência contra a mulher - uma visão multidisciplinar. Brasília: Secretaria especial de políticas públicas para as mulheres, 2005.

CAULFIELD, Sueann. Em defesa da honra: moralidade, modernidade e nação no Rio Janeiro (1918-1940). São Paulo: Editora da Unicamp, 2000.

ESTEVES, Martha de Abreu. Meninas Perdidas: os Populares e o cotidiano do amor no Rio de Janeiro da Belle Époque. Rio de Janeiro: Paz e terra, 1989.

FAUSTO, Boris. Crime e cotidiano: a criminalidade em São Paulo (1880-1924). $2^{\mathrm{a}}$ ed. São Paulo: Edusp, 2001.

FOUCAULT, Michel. História da sexualidade. 1 a vontade saber. Rio de Janeiro: Edições Graal,1988.

IZUMINO, Wânia Pasinato. Justiça e violência contra a mulher: o papel do sistema judiciário na solução dos conflitos de gênero. São Paulo: Annablume: FAPESP, 2004.

MAIA, Clarissa Nunes. Policiados: controle e disciplina das classes populares na cidade do Recife, 1865-1915. 250 p. Tese (doutorado), Universidade Federal de Pernambuco, Tese (doutorado), Universidade Federal de Pernambuco, CFCH, Recife, 2001. 